\title{
Sport, Glocalization, and the New Indian Middle Class
}

\begin{abstract}
Focusing on the structure and influence of transnational sport-namely the Commonwealth Games and fitness culture within the context of contemporary India-we draw on observations derived from empirical research to explore the complex interrelationships between economic liberalization, globalization, and consumer capitalism. Our argument centres on the processes through which contemporary Indian sport culture is being re-made within the image of India's new middle class; a set of processes that simultaneously contributes toward the hegemony of India's protuberant new middle class and thereby patently re-inscribes the social inequities and polarities evident within Indian life more generally. Through a contextual consideration of the economic liberalisation policies and allied neoliberal ideologies that propelled the new middle class' emergence (Antonio, 2007), and the consumer culture through which its identities are substantiated and boundaries demarcated (Bauman, 2001), we point to those bodies valorized (productive, consumptive and functional) and those pathologised (impoverished, underserved and disposable) within a transnational sporting culture that espouses the dictates of neoliberal polity, policy and body politics.
\end{abstract}

Keywords: Sport; India; Glocalization; New Middle Class; Economic Liberalisation; Consumer Culture 



\section{Sport, Glocalization, and the New Indian Middle Class}

\section{Introduction}

Within contemporary urban India, the conspicuous consumption of global (read: luxury or elite) brands, commodities, and services, plays a crucial role in distinguishing membership of the new Indian middle class, and for distancing "prosperous middle class consumers from those who are not part of this group" (Mathur 2010, p. 219). Doubtless prompted by rising levels of affluence and disposable income among certain sections of the populace, the concerted expansion of transnational brands into the Indian marketplace has rendered the consumerist lifestyles of the new Indian middle class unselfconsciously transnational in their aspiration, orientation, and display (Munshi 2001). As a consequence, "the self-monitoring and self-regulating gaze of the new middle class consumers" (Brosius 2010, p. 330) has normalized (for established and aspirant members) a taste for, and position within, the flows of transnational culture and capital. In doing so, and through specific consumption choices, the new middle class distinguish their cosmopolitan selves from the locally bound throng (Radhakrishnan 2008). It would be remiss, however, to assert that the new Indian middle class identity is exclusively global in its orientation. As Brosius (2010 p. 331) identified, cosmopolitan Indians are adept at "compartmentalizing their identities and ways of life", indeed, there is compelling evidence that much of contemporary Indian culture, including films, television, literature, the internet, food, leisure, and sport, has been glocalized (Robertson 1995); such that the new Indian middle class is characterised by its "glocal competence" in productively melding global and local influences in realising their complex identity projects (Brosius 2010, p. 13).

In the current paper, our focus is on the complex relationships between the (real and imagined) actions, attitudes, and experiences of the new middle class grouping and the structure, form, and influence of contemporary Indian sport culturesi. In particular, following a contextualization of the contemporary Indian formation and the place of the new Indian middle class therein, the discussion focuses on two distinct empirical sites, exploring the complex interrelationships between economic liberalization, globalization, and consumer capitalism, that frame contemporary Indian sport culture: the 2010 Delhi Commonwealth Games (CWG); and, the transnational cultural practices and corporeal politics of Indian fitness culture. In so doing, 
we explicate the interpenetration of global universalisms and local particularisms within, and through, Indian sporting structures and experiences, the specificities of India's protuberant new middle class (Fernandes 2006), the economic liberalisation policies and allied neoliberal ideologies that propelled the emergence of the new middle class (Antonio 2007), and the consumer culture through which its identities are substantiated, and boundaries demarcated (Bauman 2001) ii.

\section{Glocalization and Sport}

To understand sporting forms, spectacles and practices, we require a general recognition that "the local and the global are mutually constitutive, although the exact nature of this 'mutual constitution' remains to be specified, and has yet to be adequately theorized" (Grossberg, 1997, p. 9). This requires holding together the 'complementary and interpenetrative' relationships between the global and the local that are manifest within sport, and, following Robertson (1995) recognizing that the global is complicit in the 'creation and incorporation' of local sporting cultures, and vice versa. We thus locate ourselves theoretically in the language of glocalization. In recognizing the "mutually implicative" tendencies of homogeneity and heterogeneity (Robertson, 1995), glocalization refers to the processes and practices—some intended, others unintended-whereby the specificities of the local culture generatively interpenetrate the contingencies of global networks and flows. Robertson (1995) advanced the notion of glocalization as a solution to the positing of global homogenization, against global heterogenization, and as antagonistic explanatory framework pertaining to the effects of globalised modernities. Hence, through the conceptualizing of the glocal condition, and allied processes of glocalization, it becomes possible to discern constitutive relations linking the global and the local, that explain the similarities and differences evident within, and between, contemporary societies.

Glocal conceptualizing has been fruitfully engaged within numerous empirical strands of scholarly research; nonetheless, there presently exists a dearth of analyses of glocalized sport forms (e.g. Giulianotti \& Robertson, 2007; Silk \& Manley, forthcoming). This absence is particularly perplexing since modern sport forms are inveterately global in their organization and structure, while they oftentimes remain defiantly local 
in the manner through which they are performed and experienced. As such, in thinking about Indian sporting formations, there is a need to bold together ways in which 'local' sport has, in many respects, been created, influenced and penetrated by global forces and processes_-such that it is glocal. In seeking to redress the lack of sport-oriented examinations of glocalization, we focus on the complex relationships between the structure, form, and influence of contemporary Indian sport, and the (real and imagined) actions, attitudes, and experiences of the new middle class grouping, which has become the primary referent for the liberalizing and globalizing impulses of contemporary Indian society (Brosius, 2010, Fernandes, 2004, Mathur, 2010). The empirical sites that we examine here—namely the 2010 Commonwealth Games and urban fitness cultureexplicate the interpenetration of global universalisms and local particularisms within, and through, Indian sporting structures and experiences. At the same time, they draw attention to the complexities of sport as a conjuncturally contingent formation, and the myriad interrelationships through which it is constituted. As a consequence, the glocal nature of Indian sport is identified through an exploration of its necessary, and generative, interrelationships with other glocalized dimensions of contemporary Indian society.

\section{Contextualizing the New Indian Middle Class}

Our focus on the new Indian middle class should not belie the fact that it is but one segment of the expansive, yet heterogenous (cleaved by interlocking ethnic, religious, caste, and regional affiliations) (Nijman 2006), Indian middle class formation.iii As an influential cultural, economic, and political entity, this predominantly urban, professionally employed, and relatively well-salaried cohort, is widely perceived to be a key agent in, and beneficiary of, India's unfolding economic miracle (Brosius 2010, Fernandes 2004, Fernandes 2006, Lal 2008). Furthermore, as Baviskar and Ray (2011, p. 23) illustrated, this relatively small and internally differentiated social formation has "become a powerful unifying idea that drives political discourse on matters ranging from economic and social policy to international affairs" and, as we hope to demonstrate, sport.

Like its middle class predecessors in pre-colonial, colonial, and the immediate decades of postcolonial India (Baviskar and Ray 2011, Misra 1960), the new Indian middle class is a representative subjectivity synonymous with the Indian nation as a whole. Just as those within the "learned professions" 
dominated the colonial iteration of the Indian middle class (Misra 1960, p. v), so the corporate and consumeroriented new middle class subject is the contemporaneous Indian "everyman" (Baviskar and Ray 2011) constituted by, and constitutive of, the contingencies of the "new India" (Radhakrishnan 2008). As a consequence, this influential formation has to be understood in relation to the political, economic, and social transformations that shaped India in the decades following independence, and particularly those enacted over the past two decades.

Propelled by the Nehru government's (1947-1964) democratic socialism, post-independence India adopted economic development policies underpinned by a commitment to state planning and ownership, industrial regulation, and market protection (Reed 2002). Realised through a series of Five-Year Plans initiated in 1951, these inward-oriented monetary and fiscal policies (Krueger 2002) controlled private economic activity, while stimulating government-led industrialization. The aim was to secure Indian economic self-reliance, and simultaneously increase the standard of living for the Indian populace (Srinivasan and Tendulkar 2003). Adherence to these policies meant, by the late 1970s and early 1980s, the Indian economy was relatively insulated from world markets; illustrated by India's share of world merchandise exports declining from $2.2 \%$ in 1948 , to $0.5 \%$ in the early 1980 s (Srinivasan \& Tendulkar 2003, p. 8). Allied to this, from the late 1940s to 1980, a combination of economic inefficiencies, budget deficits, and restricted sources of capital investment (Das 2011), meant India experienced a low rate of economic growth averaging less than $2 \%$ annually (Krueger \& Chinoy 2002).

In an effort to stimulate what had become a stagnating Indian economy-and to some degree compelled by the global shift toward economic liberalization (Desai 2007, Harvey 2005)—beginning in the mid-1980s, the Indian government implemented a series of liberalizing economic reforms. Due to a combination of opposition from the "business sector, the bureaucrats, the rural sector and the traditionally highly vocal and influential leftist-nationalist intelligentsia" (Pedersen 2000, p. 266), this initial phase of reform ultimately failed. Furthermore, it created the conditions of economic crisis that justified the enactment of more radically revisionist measures. ${ }^{\text {iv }}$ The ensuing economic reforms were focused on both discrete measures designed to stabilize the Indian economy (tightening monetary policy, devaluing the rupee, and 
reducing the fiscal deficit through spending cuts), and more expansive changes focused on liberalizing the Indian economic structure as a whole (privatizing public enterprises, creating business-friendly labour laws, and opening India's financial sector to foreign investment) (Pedersen 2000, Topolova 2007). As such, they heralded a shift "from an inward-oriented, state-led development strategy to a policy of active reintegration with the world economy" (Srinivasan \& Tendulkar 2003, p. 2).

By the beginning of the twenty-first century, the success of these policies was demonstrablev: India's economic transformation captured the "imagination of policymakers, financial markets, analysts, as well as the general public" (Hall and Poloz 2007, p. 771). However, the celebratory discourse that routinely framed India's liberalizing economic reforms belied the socio-economic inequalities that not only endured, but were, if anything, accentuated following their implementation (Deaton and Dreze 2002, Nagaraj 2000, Pal and Ghosh 2007, Pedersen 2000, Rizvi 2007). The financial gains derived from the liberalization of the Indian economy have largely been experienced by the capitalist elite, and those members of the middle class able to take advantage of the new forms of employment, particularly those within the "information technology and business processing industries that make up the so-called new economy" (Mishra 2006). Conversely, India's widely touted economic miracle (Institute 2007) has failed to relieve India's elevated levels of extreme poverty. Not only have India's residual poor been circumvented by the new modes of technology and education intensive employment that accompanied the globalization of the Indian economy, they have simultaneously suffered from attendant price increases across various consumer sectors (Pal and Ghosh 2007, Spencer 2010). vi India's liberalizing economic policy has thus contributed to the accentuating of inequality within the nation, by strengthening the financial power and political influence of the capitalist and middle classes, at the expense of the massed ranks of the impoverished (Ahmed et al. 2011).

The diminutive material size of the new India middle class is secondary to its symbolic influence, and attendant cultural, political, and economic effects (e.g. Brosius 2010, Fernandes 2004, 2006, 2011, Mathur 2010). Whilst the values, aspirations, and experiences of the old middle class were framed by the twinned influences of Nehruvian statism and Ghandian austerity, those of its new middle class successors were propelled by the economic liberalisms, corporatist compulsions, and consumerist orientations of global 
capitalism (Brosius 2010, Fernandes 2011). Transnational corporations played a key role in establishing information technology and service sectors within many of India's metropolitan hubs and, crucially, for creating the professional white-collar workforce whose stable, salaried, and relatively well-paid employment (when compared with average levels of workforce remuneration) (Banerjee and Duflo 2008) provided the financial vehicle for entry into the consumerist lifestyle of the new middle class. Simultaneously, and with regards to the globalization of consumer culture, the intensified incursion of transnational brands and products into the Indian consumer marketplace stimulated new consumer practices, aspirations, and subjectivities, of which the new Indian middle class is the most notable exemplar (Derné 2008; Munshi, 2001). Fernandes (2004, p. 2424) goes so far as to suggest that the new middle class is less a coherent and clearly bounded social grouping, and more a commercially and politically constructed "invention": a "symbolic, dynamic construct in which consumption markers play an important role" (Donner et al. 2008, p. 327).

Created by a post-liberalization conjoining of both the state's (through government policy directives and statements), and commercial culture's (through television, cinema, print, and internet outpourings) corroborative imaginings, the white-collar professional and consumption-oriented new Indian middle class subject was discursively embodied, and thereby rendered visible, through the idealised consumer-citizen. Unselfconsciously reveling in, and thereby normalizing, the "practices of consumption associated with newly available consumer goods in liberalising India" (Fernandes 2004, p. 2418), the new middle class is less identified with the state, "increasingly defines itself through cultural and consumerist forms of identity" (Rajagopal, 2011, p. 1003). Rajagopal continued, in the late 1970s, while an "artifact of state policies" the political shift away from the state toward more consumerist forms of identification and politics, resulted in a "newly-fashioned investing 'middle class"”..."acquiring a life of its own” with ramifications of Indian cultural, political, and economic life (2011, p. 1009): The implicitly politicized consumer-citizen subjects of the new Indian middle class simultaneously validated the liberalizing reforms, and corporatist structures, that facilitated the (re)integration of Indian society into the world economy (Srinivasan \& Tendulkar 2003). 
The normalization of the new Indian middle class consumer-citizen as the idealised representation of consumer India (Bijapurkar 2009), has proved culturally, politically, and economically effective, due to its ability to interpellate wider realms of the Indian populace. Embedded in the seductive representations of the new Indian middle classes' consumption-based lifestyles are discrete forms of commodity consumption (i.e. mobile phones, laptop computers, flat screen televisions), and indeed display, to which broader sections of the middle and upper working classes "can [reasonably] aspire" (Fernandes 2011, p. 71). Through such consumptive acts, the boundaries to the new Indian middle class are seemingly open and surmountable. However, in their entirety, the comprehensively commodified and affluent lifestyle assemblages portrayed through commercial media discourse are unattainable to all but the upper echelons of Indian society. Nonetheless, and especially as articulated through the workings of the commercial media looking to popularize aspirational consumerist sensibilities, the normalized new middle class lifestyle is seductively expressed as an effect of individual enterprise and choice.

This pervasive neoliberal understanding denies the influence of the extant structures of disadvantage and inequality (Fernandes 2011); structures which preclude many from being able to take advantage of India's expanding education, employment, and earning opportunities. Despite the egalitarian assumptions of the Indian economic transformation, the majority of the Indian populace find their access to the consumptive sources of social distinction and status significantly restricted. Hence, the idealization of the new Indian middle class subjectivity — as encapsulating a lifestyle and life chances accessible to large swathes of the Indian populace-encourages a pernicious attitude towards poverty and the poor. As is apparent within numerous other neoliberal contexts (Wacquant 2007, 2009), so in India the (urban and rural) poor become pathologized and demonized for their very poverty; for not taking advantage of the opportunities seemingly afforded by what Thomas L. Friedman (2004) referred to as "the great Indian dream." It is their perceived indolence, rather than any widespread acknowledgement of extant socio-structural impediments, that justifies a raft of neoliberal governmental policies which accentuate, as opposed to ameliorate, the exclusion and marginalization of India's impoverished throng (Baviskar 2011, Bhan 2009, Rao 2010). For this reason, consumer India's (Bijapurkar 2009) socio-cultural politics of (bodily) distinction are inextricably linked to a 
socio-spatial politics of exclusion, both of which are engaged within the following analyses of the CWG and of fitness culture, as sporting symptoms of the new Indian middle class order.

\section{The 2010 Delhi Commonwealth Games: Sport and the Socio-Spatial Politics of Exclusion}

Implicit within the instantiation of a consumer culture, driven and defined by the practices and preferences of the new Indian middle class, is an efficient process of social exclusion. Quite simply, those unable to afford access to the distinguishing "consumption markers" of new Indian middle class (Donner et al. 2008, p. 327) are simultaneously rendered visible as economically and culturally impoverished subjects and "rendered invisible and forgotten within the dominant national political culture" (Fernandes 2004, p. 2416, italics added). Hence, as Indian political culture becomes dominated by neoliberal ideologies and actors—advancing policies which privilege and celebrate the new Indian middle class for being productive citizens responsible for the rise of the new India—so there exists a growing political and cultural indifference towards poverty and the poor (Fernandes 2004, Rizvi 2007). The demonization of the Indian poor positions them as sources of national incapacitation threatening India's social and economic miracle. This justifies policies that either ignore the structural disadvantages and inequalities responsible for their plight, or, more proactively, stimulates initiatives designed to expunge them from the landscape of India's aspirant world cities (Bhan 2009, Rao 2010). Of course, and as numerous theorists have identified, social hierarchies and relations are unavoidably implicated in, and concretized by, particular spatial organisations and relations (Massey 1994, Peck 2004, Brenner and Theodore 2002). Within the Indian context, the spatial manifestations of “transnational neoliberalism” (Peck 2004) are evidenced within dualistic initiatives designed to create "world class" cities for the deserving new Indian middle class and to simultaneously excoriate the undeserving poor from newly reconfigured and beautified urban environments, through processes of spatial purification and urban cleansing (Fernandes 2004).

Despite being mired by charges of corruption, inefficiency, poor safety, and sub-standard hygiene (Anon 2010, Banerjee and Ray 2010, India 2011) our interest in the CWG centres on its relationship to the neoliberal socio-spatial politics of exclusion. Those primarily responsible for securing and delivering the 
CWG—namely the ruling government; the chief minister of Delhi, Sheila Dikshit; and, the Games organizing committee led by Suresh Kalmadi-looked to the Games as a means of advancing the city as a global metropolis illustrative of India's escalating economic growth, increasing influence within international politics, and unequivocal cultural significance. The official bid document confirms such observations: "these Games will showcase New Delhi, the capital of India, to the world and promote it as a global city of an emerging economic power" (quoted in Majumdar and Mehta 2010, p. 5). Indeed, the CWG represented the culmination, and arguably most visible expression, of more than a decade of initiatives targeted as symbolically reinventing, and materially restructuring, Delhi as a world-class city (Bhan 2009, Ghertner 2010, Rao 2010).

As with other such examples of entrepreneurial urban governance strategies focused on the use of sporting mega-events to create a palatable glocal image to attract inward investment and tourism (see Silk \& Manley 2012), the CWG necessitated large-scale expenditure of public funds on the construction of facilities, and related infrastructure enhancements (Hall 2006) vii. In order to justify such expenditure of public monies within a "struggling third world city" compromised by deficiencies in the housing, education, health, and sanitation sectors, city officials, and CWG organizers alike, mobilized familiar neoliberal trickle-down rhetorics (Baviskar 2007). Through initiatives such as the "Come Out and Play" promotional film, the Games were represented to the Delhi populace as a credible public investment, from which all would accrue tangible benefits; therefore encouraging all Delhiites, rich and poor alike, to assume the role of stakeholders in the success of the Games and unite behind it. This CWG promotional was part of a broad-based public relations assault legitimizing the dominant narrative pertaining to the city's broader development: a "shared aesthetic sense of how the city should look ... enhanced by the general celebration of middle-class consumptive lifestyles and spaces" (Ghertner 2010, p. 200). The intentions of such directives was plain: To "produce governable subjects-individuals who evaluate and act upon the social world through lenses provided by government" (Ghertner 2010, p. 186); the primary lens being that which focused on the CWG as proof positive of Delhi's standing as a world-class city in the making (Baviskar 2006). 
Through the demolition of select urban spaces and populations, CWG organizers intentionally created the blank campus upon which to create the high-tech infrastructure, commercial and habitation structures, and beautified environments attuned to the consumptive and aesthetic expectations of the new Indian middle class. The CWG was thus a central tool in the spatial purification and urban cleansing of Delhi in a number of important ways. The most evident human cost of hosting the games for some Delhi residents was forced eviction and relocation (Puri and Bhatia 2009). Since slum clearance and redevelopment was an established feature of Delhi's urban development strategy, that associated with the CWG was simply the most high profile example of the concerted removal and resettlement of Delhi's deprived populations away from the core spaces of the globalizing metropolis (Bhan 2009, Dupont 2008, Rao 2010). Indeed, the CWG acted as a compelling deadline for the-ultimately unrealistic_-goal of a "slum free Delhi 2010" (Rao 2010, p. 403).

Despite failing to reach their targets, and according to the Hazards Centre (an international NGO concerned with issues of forced displacement), since 2005 over 200,000 families have been evicted from their homes, as a result of clearance schemes connected to the CWG (Centre 2010, p. 8). 27,000 families alone were forcibly evicted from the Yamuna Pushta area, on the banks of the Yamuna River (Baviskar 2006). Yamuna Pushta's displaced inhabitants found themselves living in sites located on the outskirts of the city, and far removed from the vibrant economic centres where they had previously eeked out an existence. "The Village"-the newly constructed accommodation complex housing athletes during the CWG- which replaced their shanty dwellings, waited for a more lucrative future. Within the original bid for the CWG, upon the completion of the Games, "The Village" was intended to be used as dormitory accommodation for Delhi University students. Once awarded the Games, the organizing committee changed direction, and secured a private real estate firm to develop "The Village" into high-priced luxury apartments (Majumdar \& Mehta 2010, p. 37). Real-estate company Emaar MGF subsequently marketed village apartments as part of an exclusive residential enclave; a "landmark address", "lifestyle statement", and the opportunity for "global living inspired by an international event” (Emaar MGF 2010).viii

The bid document prepared by the CWG Organizing Committee budgeted 7.5 crore rupees $(\$ 1.66$ million) for expenses related to the beautification of Delhi. By the time the Games were due to begin, the Delhi 
city government had spent 344 crore rupees (about $\$ 76$ million) on the improvement of roads and footpaths in and around the Games venues alone (Mishra et al. 2010, p. 13). Plans for beautification included improving streetscapes, new road signage, potted plants around venues, resurfacing roads, improving sidewalks and footpaths, and the construction of bicycle paths. However, there were also human dimensions to the beautification agenda. Given the perceived problem of Delhi's numerous slum settlements, city officials erected strategically positioned bamboo screens, to prevent tourists, athletes, and visiting dignitaries from seeing the conditions and levels of Delhi's poverty: this façade serving as a buffer between the CWG constituency, and the shanties lining many of the main throughfares to "conceal the sights" and "present a good face of Delhi during the Commonwealth Games" (Chief secretary of Delhi, Rakesh Mehta in Mishra et al. 2010, p. 13). Crucially, in adopting this strategy, it was not "just poverty that [was] 'aestheticized', but city space itself' (Bhan 2009, p. 140). The socio-spatial exclusion and demonization of Delhi's poor is indicative of a new Indian economic order reconfigured around the practices, identities, and ethos of consumption and technological innovation; the traditional Indian labouring class have been effectively excluded from the global economic order, cast on the scrapheap of surplus labour leaving a "majority of the working population outside the dynamics of the great transformation" (Sanyal \& Battachryya, 2009, p. 43, see also Chaterjee, 2008; Sanyal, 2007)ix. In this sense, Delhi's poor are denied their very "right to the city"; to their claim to being "legitimate urban citizens" (Bhan 2009, p. 141): a sentiment clearly expressed by the Chief Officer of the Delhi Slum Survey (in Ghertner 2010, p. 203), who espoused, "Delhi is developing. It is cleaning up. Only the best people will live in Delhi. ... All the deserving people will stay, but everyone else will have to go." Thus, as a material expression of an "actually existing neoliberalism" (Brenner and Theodore 2002), the entrepreneurial approach to urban governance and development epitomised by the CWG implicitly valorizes the new Indian middle class subject, while simultaneously positioning its discursively constitutive and legitimising antithesis-the Indian impoverished-“as economically unviable, environmentally harmful and criminal ... a homogenous category inseparable from the built environments of the illegal 'slums' that they inhabit" (Bhan 2009, p. 141). 


\section{Fitting in India}

As the tentacles of consumer culture permeate ever more aspects of Indian society, so the inexorable rise of the fitness industry's myriad products and services are making inroads into Indian cultural practices and onto the bodies of the new Indian middle class who have both the time and income necessary to concentrate on body maintenance and enhancement regimens; on their bodies as commodified projections of the self (Dworkin and Wachs 2009). This regime of conspicuous consumption, through which social status is derived and displayed, incorporates not only the branded products that adorn the body and its attendant lifestyle, but also the body itself, perhaps an inevitable consequence of the necessary relationship between consumption and the body within consumer capitalism (Dworkin and Wachs 2009, Maguire 2001, 2008, Monaghan 2007; Shilling, 1993). With consumer culture incorporating the body as a central subject and object of consumption, it is unsurprising that the embryonic Indian fitness industry has capitalized on the new middle class body as a corporeal commodity. Despite being in a 'primitive [sic] stage' of development with reportedly 765 fitness clubs serving the population of 1.3 billion people (IHRSA 2008, p. 27), the Indian fitness industry is rapidly expanding to service the increased spending power of India's new middle class, and their burgeoning desires to sculpt their own culturally idealized body projects. As Vibha Nanabhai, head of marketing for Indian gym chain Talwalkars identified, fitness center membership is no longer limited to the elite, we are seeing people from the middle class attend our centers' (quoted in Das 2010, p. 19). Within India's major metropolitan areas, small, non-descript and often hidden independent gyms (see (Dutt 2008) compete with transnational fitness chains (e.g. Gold's Gym, Fitness First) located in spectacularized consumptive environments complete with air-conditioning, the latest workout equipment and regimes. Gold's Gym appears to be particularly aggressive with plans to add an additional 25 gyms to their current operation (50) (Anon 2011b).

That American-based corporations are looking to further their presence in the Indian fitness market, follows an established trend of multinational entities looking to benefit from India's growing consumptive power within many other commercial sectors. The multinational fitness industry has been a relative latecomer to the Indian market; arguably attributable to the prevalence of India's historically entrenched, and diverse, 
indigenous physical culture (McDonald 1999) which incorporates its own forms of exercise regimen and related health. This was likely confounded by India's relative economic and (popular) cultural isolation: not until the period immediately following India's initial phase of economic liberalization were Western fitness and exercise practices and ideals manifest within Indian culture to any concerted degree. Certainly, the CocaColonization (Flusty 2005) of Indian culture (a processual metaphor for the influx of multinational brands, oftentimes American in origin and/or signification) occurred decades before the multinational fitness industry began to make in-roads into Indian body culture. With a "muscled, taut body" as something of a "cultural icon ... [that] flaunts to the world that one now cares for oneself and how one appears to others" (Munshi 2001, p.86) replacing well-fed embodiments of wealth, the bodily ideal within India's fitness centers is distinctly Western in form. As a result, multinational corporate fitness chains, such as Gold's Gym and Fitness First, are over-determined by their innate Western provenance and orientation, and make little effort to distance themselves from it. As an indication of this, many commercial fitness centers in Delhi hire personal trainers from Western nations, because they 'bring with them exotic exercises that Delhiites find interesting' (Arora 2010, p. 2). In this sense, the fitness industry is not compelled to adopt glocalization strategies in India in order to 'overcome barriers of foreignness' (Matusitz and Reyers 2010, p. 243); preferring instead to capitalize upon the cultural Otherness/foreignness they, quite literally, embody. ${ }^{\mathrm{x}}$

The constitution of elite social identities and status groupings in contemporary Indian culture 'appears' to be embedded and expressed through conspicuous displays of 'cosmopolitan consumption' (Derné 2008, p.103), especially as it pertains to women's involvement. Much of this is realised through the new middle class' consumption of Western branded fashion and beauty apparel, accoutrements, and services (Brosius 2010, Thekaekara 2006). However, as displayed and idealized throughout the gamut of Indian public culture—film stars, television celebrities, beauty queens, catwalk and advertising models (Munshi 2001)— 'transnational standards of beauty' are also shaping the new middle class body, particularly as they relate to 'an emphasis on thinness' (Derné 2008, p.102). For some, this is tantamount to a disavowal of Indian culture and identity, in favour of transnational identifications: Indian women "are working out, they are getting smaller and looking more like American women"' (Derné 2008, p. 104). In response, and perhaps as a form of 
corporeal glocalization, or embodied rooted cosmopolitanism, it is instructive to turn to the case of India's high profile beauty queens. Their cultural presence and influence has played a significant role in creating and normalizing a new Indian female subjectivity within the post-liberalization epoch (Munshi 2001, Parameswaran 2004, Runkle 2004), which remediates the global-local tensions evident within new middle class existence. As Parameswaran (2004 p. 366) identified:

the symbolic resurrection of the beauty queen as a woman who treasures her cultural heritage even as she masters practices of global consumer culture interpellates readers as patriotic and cosmopolitan citizen-consumers. The discursive ingredients in the recipe for the successful beauty queen-an authentic Indian heart that pulses beneath the outer cloak of the West's body politic-compel audiences to assemble their identities as skilful, hybrid citizens whose pursuit of material culture blends harmoniously into their nationalist subjectivities.

While the realisation of new middle class ideals of femininity (and, for that matter, masculinity) are rooted in various forms of transnational consumption, beneath every "international" look on the outside' there exists a 'real "home” girl at heart' (Derné 2008, Munshi 2001, p. 91). Thus, the disciplinary subjugation of the female Indian body according to 'Western ideals of the perfect body-perfectly shaped, toned and exercised' (Munshi 2001, p. 87) becomes a confirmation of both India's global awakening, and its local distinctiveness: a celebration of transnational sexism in embodied form ${ }^{\mathrm{xi}}$.

\section{Conclusion: Glocalized Mutations}

Each and every neoliberal transition, in this sense, is distinctive, though each also remakes the relationship between the part (an actually existing neoliberal case) and the whole (the abstraction we might provisionally term neoliberalism-in-general). Moreover, no transition to neoliberalism was ever solely an 'inside job', nor was it just an 'external imposition' ... or this is a locally embedded yet transnational process (Peck 2004, p. 395). 
Although Peck (2004) speaks to but one dimension, neoliberalism, of the Indian conjuncture articulated herein, his concept of "mutations" is instructive in two ways. First, it offers another way of conceptualizing the glocalized nature of the various phenomenon we have discussed, as corollaries of the Indian context within which they are dialectically embedded. Second, his allusions to transmutation suggest the fluid and variegated manner in which India's sporting, new middle class, economic liberal, neoliberal, and consumer culture mutations are constitutively interdependent. With such interrelationships in mind, it is possible to view contemporary Indian sport culture (as exhibited in these empirical sites), as having been remade within the image, and simultaneously contributing toward the hegemony of, the new Indian middle class in its role as the central agent in the "revisioning of the Indian nation" (Fernandes 2006, p. 66). Masquerading as a socially cohesive, democratic, and nationally representative space, Indian sport would appear to be anything but. Albeit in different permutations-and to differing intensities-the design, operation, and experience of the CWG and the everyday experiences and shaping of fitness cultures / bodies patently re-inscribes the social inequities and polarities evident within Indian life more generally. These complex sporting sites compound the already enacted biopolitics of disposability (Giroux 2008) through which impoverished and underserved bodies are deemed surplus to the demands of the capitalist order. They are ignored by the neoliberal polity, due to their inability to contribute "neither to production nor to the realization of value because they are unable to consume: re-imagined instead as a relative surplus population" (Smith 2011, p. 16). Conversely, the valorized productive and consumptive new Indian middle class body expects, and largely experiences, the (sporting) world constructed in his/her image. For, neoliberal states, such as India, "do not see their role as one of counteracting the inequities of capitalism but rather enhancing its field of operation” (Smith 2011, p. 27).

To be sure, periodic expressions of resistance to Indian sport's patent inequities do arise; however, their effectiveness is compromised by the combined economic might, ideological weight, and cultural momentum of the new Indian formation. But one example, the mismanaged, corruption-mired, and inhumane practices associated with the CWG sparked the Anna Hazare-led anti-government protests, marking "the first time India's new, urban middle class has put aside creature comforts and personal ambition 
and taken to the streets for a political cause" (Denyer and Lakshmi 2011)xii. The generic Maoist may-more likely may not-be knocking at the gates of contemporary India. Meanwhile, Delhi's new middle classes, ever vigilant to the next socially distinguishing consumptive opportunity, are more likely to be on their computers securing the exorbitantly priced tickets to the Formula 1 Airtel Grand Prix of India (with Lady Gaga as the after race entertainment in the 2011 iteration), irregardless of the on-going accusations related to the forced acquisition of land from local farmers for the Buddh International Circuit (Nelson 2011). So, another mutation of transnational sport-arguably the next "new planetary vulgate" (Bourdieu and Wacquant 2001, p. 1)-becomes enmeshed in the hierarchical economies, cultural expressions, corporeal compositions, and attendant social relations, of India's polarized populace.

\section{References}

Ahmed, W., Kundu, A. \& Peet, R. (2011). Introduction. In: Ahmed, W., Kundu, A. \& Peet, R. (eds.) India's new economic policy: A critical analysis New York: Routledge.

Aiyar, M. S. (2010). The Commonwealth Games. The Radical Humanist.

Anon. (2010). Commonwealth Games India's Shame. The Times of India, September 22.

Antonio, R. (2007). The cultural construction of neoliberal globalization. In: Ritzer, G. (ed.) The Blackwell Companion to Globalization. Malden, MA: Blackwell.

Banjeree, A. V. \& Duflo, E. (2008). What Is Middle Class about the Middle Classes around the World? The Journal of Economic Perspectives, 22, 3-28.

Banjeree, R. \& Ray, A. (2010). World heaps scorn on "disgusting" village. The Times of India, September 22.

Bauman, Z. (2001). Consuming life. Journal of Consumer Culture, 1, 9-29.

Baviskar, A. (2006). Demolishing Delhi: World class city in the making. Mute, 2, 88-95.

Baviskar, A. (2007). Delhi's date with the Commonwealth Games 2010. Games Monitor, August 11.

Baviskar, A. \& Ray, R. (2011). Introduction. In: Baviskar, A. \& Ray, R. (eds.) Elite and Everyman: The Cultural Politics of the Indian Middle Classes. New Delhi, India: Routledge.

Bhan, G. (2009). "This is no longer the city I once knew". Evictions, the urban poor and the right to the city in millennial Delhi. Environment and Urbanization, 21, 127-142. 
Bijapurkar, R. (2009). We are like that only : understanding the logic of consumer India, New Delhi, Penguin.

Bourdieu, P. \& Wacquant, L. (2001). Neoliberal speak: Notes on the new planetary vulgate. Radical Philosophy, $2-5$.

Brenner, N. \& Theodore, N. (2002). Cities and the Geographies of “Actually Existing Neoliberalism". Antipode, 34, 349-379.

Brosius, C. (2010). India's Middle Class: New Forms of Urban Leisure, Consumption and Prosperity, London, Routledge.

Centre, H. (2010). Heritage games: Cleaning up the debris. New Delhi: Hazards Centre.

Chaterjee, P. (2008). Democracy and economic transformation in India. Economic \& Political Weekly, April 19, 53-62.

Chen, S. \& Ravallion, M. (2008). The developing world is poorer than we thought, but no less successful in the fight against poverty. Development Research Group, World Bank.

Das, D. K. (2009). Globalisation and an emerging global middle class. Economic Affairs, 90-92.

Das, D. K. (2011). Indian economy: Growth performance and prospects of transitioning the growth trajectory. Journal of Asia-Pacific Business, 12, 171-193.

Deaton, A. \& Dreze, J. (2002). Poverty and Inequality in India: A Re-Examination. Economic \& Political Weekly, 37, 3729-3748.

Denyer, S. \& Lakshmi, R. (2011). Anna Hazare inspires young, middle-class awakening in India. The Washington Post, September 14.

Derne, S. (2008). Globalisation On The Ground: Media and the Transformation of Culture, Class, and Gender in India, New Delhi, Sage.

Desai, R. (2007). Dreaming in Technicolour? India as a BRIC Economy. International Journal, 62, 781-804.

Donner, J., Rangswamy, N., Steenson, M. W. \& Wei, C. (2008). "Express Yourself” and "Stay Together": The Middle-Class Indian Family. In: Katz, J. E. (ed.) Handbook of Mobile Communication Studies. Cambridge, MA: MIT Press. 
Dupont, V. (2008). Slum demolitions in Delhi since the 1990s: An appraisal. Economic and Political Weekly, 43, $79-87$.

Fernandes, L. (2004). The politics of forgetting: class politics, state power and the restructuring of urban space in India. Urban Studies, 41, 2415-2430.

Fernandes, L. (2006). India's new middle class: Democratic politics in an era of economic reform, Minneapolis, University of Minnesota Press.

Fernandes, L. (2011). Hegemony and inequality: Theoretical reflections on India's 'new' middle class. In: Baviskar, A. \& Ray, R. (eds.) Elite and Everyman: The Cultural Politics of the Indian Middle Classes. New Delhi, India: Routledge.

Friedman, T. L. (2004). The Great Indian Dream. The New York Times, March 11.

Gaines, E. (2005). Interpreting India, identity, and media from the field: Exploring the communicative nature of the exotic Other. Qualitative Inquiry, 11, 518-534.

Ghertner, D. A. (2010). Calculating without numbers: aesthetic governmentality in Delhi's slums. Economy and Society, 39, 185-217.

Giulianotti, R. \& Robertson, R. (2007). Forms of glocalization: Globalization and the migration strategies of Scottish football fans in North America. Sociology, 41, 133-152.

Giroux, H. A. (2008). Beyond the biopolitics of disposability: Rethinking neoliberalism in the New Gilded Age. Social Identities, 14, 587-620.

Hall, C. M. (2006). Urban entrepreneurship, corporate interests and sports mega-events: the thin policies of competitiveness within the hard outcomes of neoliberalism. Sociological Review, 54, 59-70.

Hall, P. G. \& Poloz, S. S. (2007). When Will India Reach Its Full Potential? International Journal, 62, 771-779.

Harvey, D. (2005). A brief history of neoliberalism, Oxford, Oxford University Press.

India, C. A. A. G. O. (2011). Audit report on XIXth Commonwealth Games 2010. Delhi: Union Government (Civil).

Institute, M. G. (2007). The 'Bird of Gold': The Rise of India's Consumer Market. McKinsey \& Company. 
Krueger, A. O. (2002). Introduction. In: Krueger, A. O. (ed.) Economic policy reforms and the Indian economy. Chicago: University of Chicago Press.

Krueger A. O. \& Chinoy, S. (2002). The Indian economy in global context. In: Krueger, A. O. (ed.) Economic policy reforms and the Indian economy. Chicago: University of Chicago Press.

Lal, D. (2008). An Indian economic miracle? Cato Journal, 28, 11-34.

Majumdar, B. \& Mehta, N. (2010). Sellotape legacy: Delhi and the Commonwealth Games, New Delhi, HarperCollins. Massey, D. (1994). Space, place, and gender, Minneapolis, MN, University of Minnesota Press.

Mathur, N. (2010). Shopping Malls, Credit Cards and Global Brands: Consumer Culture and Lifestyle of India's New Middle Class. South Asia Research, 30, 211-231.

Matusitz, J. \& Reyers, A. (2010). A Behemoth in India: Walmart and Glocalisation. South Asia Research, 30, 233-252.

McDonald, I. 1999. 'Physiological patriots'?: The politics of physical culture and Hindu nationalism in India. International Review for the Sociology of Sport, 34, 343-358.

McDonald, I. (2000). India. In: Coakley, J. \& Dunning, E. (eds.) Handbook of sports studies. London: Sage.

Mishra, P. (2006). The myth of the new India. The New York Times, July 6.

Mishra, S., Chaudry, S. \& Kothary, M. (2010). The 2010 Commonwealth Games: Whose wealth, whose commons? . New Delhi: Habitat International Coalition.

Misra, B. B. (1960). The Indian Middle Classes: Their Growth in Modern Times, New Delhi, Oxford University Press.

Munshi, S. (2001). Marvellous me: The Beauty industry and the construction of the "modern" Indian woman. In: MUNSHI, S. (ed.) Images of the 'modern woman' in Asia: global media, local meanings. Richmond, Surrey: Curzon Press.

Nagaraj, R. (2000). Economy since 1980: Virtuous Growth or Polarisation? Economic and Political Weekly, 35, 2831-2833, 2835-2839.

Nelson, D. (2011). Indian Formula One Grand Prix create village rift. The Daily Telegraph, August 2. 
Nijman, J. A. N. (2006). Mumbai's Mysterious Middle Class. International Journal of Urban and Regional Research, 30, 758-775.

Pandit, A. (2010). Poor banished from public spaces. The Times of India, September 28.

Peck, J. (2004). Geography and public policy: constructions of neoliberalism. Progress in Human Geography, 28, 392-405.

Pedersen, J. D. (2000). Explaining Economic Liberalization in India: State and Society Perspectives. World Development, 28, 265-282.

Puri, E. \& Bhatia, T. (2009). Commonwealth Games 2010: Displacement of persons. Centre for Civil Society.

Radhakrishnan, S. (2008). Examining the "Global" Indian Middle Class: Gender and Culture in the Silicon Valley/Bangalore Circuit. Journal of Intercultural Studies, 29, 7-20.

Rai, A. S. (2009). Untimely Bollywood: Globalization and India's new media assemblage, Durham, NC, Duke University Press.

Rajagopal, A. (2011). The Emergency as prehistory of the new Indian middle class. Modern Asian Studies, 45, 1003-1049.

Rao, U. (2010). Making the Global City: Urban Citizenship at the Margins of Delhi. Ethnos, 75, 402-424.

Reed, A. M. (2002). Corporate Governance Reforms in India. Journal of Business Ethics, 37, 249-268.

Richardson, L. (2000). New writing practices in qualitative research. Sociology of Sport Journal, 17, 5-20.

Rizvi, G. (2007). Emergent India: Globalization, Democracy, and Social Justice. International Journal, 62, 753768.

Robertson, R. (1995). Glocalization: Time-Space and Homogeneity-Heterogeneity. In: Featherstone, M., Lash, S. \& Robertson, R. (eds.) Global modernities. London: Sage.

Sanyal, K. (2007). Rethinking Capitalist Development: Primitive Accumulation, Governmentality and Post-Colonial Capitalism, Routledge, New Delhi.

Sanyal, K. \& Bhattacharyya, R. (2009). Beyond the Factory: Globalisation, Informalisation of Production and the New Locations of Labour. Economic and Political Weekly, 35-44. 
Smith, G. A. (2011). Selective Hegemony and Beyond-Populations with "No Productive Function": A Framework for Enquiry. Identities, 18, 2-38.

Spencer, C. (2010). The Culprits behind India’s Income Inequality: Neoliberal Economics and Globalization? What's responsible for India's economic inequality? Harvard College Economics Review.

Sridharan, E. (2008). The Political Economy of the Middle Classes in Liberalising India. IS AS Working Paper.

Srinivasan, T. \& Tendulkar, S. D. (2003). Reintegrating India with the world economy, Washington, DC, Institute for International Economics.

Topolova, P. (2007). Trade Liberalization, Poverty, and Inequality: Evidence from Indian Districts. In: Harrison, A. (ed.) Globalization and Poverty. Chicago: University of Chicago Press.

Wacquant, L. (2007). Urban outcasts: A comparative sociology of advanced marginality, London, Polity Press.

Wacquant, L. (2009). Punishing the Poor: The Neoliberal Government of Social Insecurity, Durham, NC, Duke University Press.

i Since McDonald (2000)) asserted that the there was a dearth of critical engagement with Indian sport, there has emerged a sizeable body of literature addressing sport and physical culture in India, including, but not restricted to: traditional forms of Indian martial arts, wrestling, yoga, football, cricket, the Olympic Games and second-order events, and, general discussions of sport within colonial and post-colonial India. There remains a noticeable absence of research examining either the glocalization of Indian sport culture, or the relationship between sport and the new Indian middle class.

ii Our contextual analysis of these specific sites are informed by empirical observations derived from immersion in India (by one of the authors), for the period June 2010 through May 2011 (a timeframe including Delhi's hosting of the CWG). The middle class positioning of the researcher facilitated access to the sporting events under question and other dimensions of the cosmopolitan and consumerist urban lifestyle with which this study is concerned. At the same time, the ability to interact with those bodies who live in abject poverty-and to situate the Self as researcher within those spaces of immense inequality-was oftentimes compromised by the very issues of class status, gender, ethnicity, and nationality which afforded access in other settings. By integrating the insights and interpretations drawn from empirical immersion, the article represents a crystallized interpretation of the phenomena under scrutiny: not a singular, inalienable truth, rather a self-consciously partial and contingent (see Richardson 2000) understanding of the glocalized nature of contemporary Indian sport culture.

iii This broader amalgam of social groupings constitute between 50 million and 250 million of India's more than 1.1 billion population (the variation resulting from the criteria used for definition) (e.g. Sridharan, 2008). iv By 1991, the Indian economy was mired by an inflation rate of $13 \%$, and an annual balance-of-payments deficit running at an annual rate of approximately $\$ 10$ billion, with state reserves reduced to a low point of two weeks of imports (Krueger and Chinoy 2002).

$\mathrm{v}$ The Indian economy experienced an average growth rate of 8.5\% between 2005 and 2010; India being positioned $10^{\text {th }}$ in 2010 on the International Monetary Fund's ranking of nations by GDP (www.imf.org) 
vi Indeed, in 2008, a research report from the World Bank (Chen and Ravallion, 2008) acknowledged that although the percentage of the Indian population living below US $\$ 1.25$ per day fell from $59.8 \%$ to $41.6 \%$ between 1981 and 2005, the growth of the Indian population in general meant the numbers of people living below this international poverty line actually increased from 421 million to 456 million over the same time period (Chen and Ravallion, 2008).

vii This equated to a budget outlay of over 70,000 crore rupees in 2010 (approximately $\$ 1.6$ billion), a more than 114 percent increase on the original 70,000 crore rupees (about $\$ 136$ million) projection in 2002 (Majumdar and Mehta, 2010, p. 13).

viii The apartments were released for sale in 2011-with prices ranging from $\$ 411,000$ for a two-bedroom apartment to $\$ 1.2$ million for the five-bedroom flat (Emaar MGF, 2010).

${ }^{i x}$ This separation of the labourer from the circuit of capital has lead to the emergence of new, informal, forms of labour among the urban poor (see Sanyal \& Bhattacharyya, 2009).

x Conversely, versions of Indian corporeal Otherness are exported to the West (e.g. Bollywood dance classes, fitness routines incorporating traditional Indian choreography and music, DhoonyaFIT) as the American fitness industry perpetually reinvents itself to sustain consumer commitment (Vora, 2010).

xi The controversy over former Miss World and Bollywood star Aishwarya Rai Bachchan and her regaining her pre-pregnancy figure is instructive here. (see e.g. http://www.dailymail.co.uk/femail/article-

2145340/India-slams-Bollywood-actress-Aishwarya-Rai-Bachchan-failing-lose-baby-weight.html)

xii In a skeptical commentary on the likely longevity of the middle class' newfound political commitment, former sports minister and MP for the Congress Party, Mani Shankar Aiyar (2010), suggested: "The only good that will come out of the Commonwealth Games would be a decision to never again bid for such games until every Indian child gets a minimum to eat, an assured basic education and a playground with trained coaches to discover the sportsperson in himself or herself. That, alas, is not part of our self-satisfied middle class dream for India which is why the Maoist is knocking at our gates." 